\title{
Cross-listing in the U.S. and domestic investor protection ${ }^{\text {is }}$
}

\author{
Thomas G. O'Connor* \\ Department of Economics, NUI Maynooth, Maynooth, Co. Kildare, Ireland
}

Received 6 February 2006; received in revised form 6 February 2006; accepted 6 February 2006

Available online 2 June 2006

\begin{abstract}
Using the change in ordinary dividend payout as a proxy for improved governance, we show that crosslisting in the U.S. is associated with enhanced protection for the minority ordinary shareholders of exchangelisted non-U.S. firms. These firms substitute dividends for enhanced governance. We find no such effect for Rule 144a Portal firms. Interestingly, we document evidence inconsistent with the legal bonding hypothesis for Level 1 OTC firms. We believe that their ability to pay lower dividends post-listing is primarily due to their ability to credibly commit to fair treatment of their minority investors, given their record for equitable treatment of their ordinary shareholders. They achieve this reputation by consistently paying out a sizable proportion of their earnings as dividends. In addition, we find that the firm-level governance of Level 1 OTC firms, as measured by the number of closely held shares improves in the post-listing period. We find no such effect for SEC Rule 144a traded firms. Our results have also important implications for the agency models of dividends. (C) 2006 Board of Trustees of the University of Illinois. All rights reserved.
\end{abstract}

JEL classification: G15; G34; G35; C34

Keywords: International cross-listing; Legal bonding; Dividend policy

\section{Introduction}

The ability of firms to finance investment opportunities, over and above retained earnings is largely contingent on the effectiveness of their domestic legal system to sufficiently protect minor-

\footnotetext{
is The paper was presented at the MMF Annual Conference under the title "Are the domestic investors of cross-listed firms better protected?"

* Tel.: +35317083452.

E-mail address: thomas.a.oconnor@nuim.ie.
} 
ity shareholders. The extant literature suggests that where the providers of capital are sufficiently protected, their required return is lower resulting in a lower cost of both debt and equity capital for firms (e.g., Hail \& Leuz, 2003). Consequently, high-growth firms domiciled in countries characterised by poor legal institutional frameworks, and thus poor investor protection, are very often constrained in their attempts to finance their growth opportunities externally (e.g., Demerguc-Kunt \& Maksimovic, 1998). Absent effective legal reform, many firms engage in substitute strategies designed to fund their investment opportunity set. For example, the extant literature suggests that such firms can engage in cross-border strategic alliances (e.g., Siegel, 2003), seek political favour (e.g., Leuz \& Oberholzer-Gee, 2006; Siegel, 2003), or commit themselves to greater protection of their minority shareholders by improving their internal firm-level governance (e.g., Durnev \& Kim, 2005; Klapper \& Love, 2004). Furthermore, a firm can substitute their domestic level governance for the superior disclosure and regulatory regime of the United States by cross-listing on a U.S. exchange or NASDAQ (e.g., Coffee, 1999, 2002; Doidge, 2004; Doidge, Karolyi, \& Stulz, 2004a; Reese \& Weisbach, 2002; Stulz, 1999; Lins, Strickland, \& Zenner, 2005). Consequently, the ability of firms to finance their growth opportunities through domestic financing, post-listing in the U.S., suggests a commitment on the part of firms to better protect their investors. ${ }^{1}$

By 'opting-in' to the U.S. governance regime, these firms endeavour to encourage investment in their firm by committing to adopt the reporting obligations of domestic U.S. firms. As such, the legal bonding hypothesis suggests that at least in terms of investor protection, investors should be indifferent between investing in domestic U.S. firms or non-U.S. American depositary receipts. However, this line of reasoning has been questioned within the literature. For example, its most vocal critics (e.g., Licht, 2003, 2004; Siegel, 2005) consistently argue that the number of SEC actions against ill-behaved foreign firms has been few, and Licht (2003) goes so far as to suggest that the enforcement laws put in place by the SEC remain largely 'illusionary' for non-U.S. firms, as non-U.S. firms are subjected to a less stringent regime than that laid out for U.S. firms. In connection, Siegel (2005) outlines that over the period from 1995 to 2001 the SEC took legal action against just five foreign firms. ${ }^{2}$ So while it appears that the holders of American Depositary Receipts (ADRs) may not be as well protected as are the holders of domestically listed U.S. firms, they do enjoy the benefits of 'Reputational Bonding' from listing in the U.S. (e.g., King \& Segal, 2004; Siegel, 2005), i.e. enhanced monitoring from financial analysts, underwriters, auditors. In support Stulz (2005, p. 1632) concludes that "Although this monitoring [from listing in the U.S.] may at times seem weak and tentative, it is monitoring that otherwise would not have taken place". Finally, Doidge, Karolyi, Lins, Miller, and Stulz (2005) conclude that such monitoring acts as a sizable deterrent preventing many firms from cross-listing.

We examine whether cross-listing in the U.S. affords additional protection to those investors who have already made the investment decision and invested in the firm, i.e. the ordinary shareholders, as opposed to those investors that invest post-listing, i.e. ADR holders. The majority of non-U.S. firms that 'opt-in' to the U.S. governance regime do not 'opt-out' of their domestic

\footnotetext{
${ }^{1}$ Ribstein (2005) outlines other alternatives to cross-listing. These include certification, a sale without listing and local incorporation. In addition, a related literature outlines how domestic exchanges have in response to sizable migrations of firms to U.S. capital markets improved their governance requirements. Dewenter, Kim, Lim, and Novaes (2005) and Carvalho and Pennacchi (2005) examine the impact of enhanced stock exchange governance regulations on firm value using Korean and Brazilian exchanges, respectively. They show that improved exchange governance enhances firm value. In a similar vein, Krishnamurti, Sequeira, and Fangjian (2003) using the two major Indian stock exchanges demonstrate how demutualized exchanges are superior to mutualized exchanges in terms of governance.

2 Joos (2003, p. 396) concludes that "At the very least, empirical work suggests that the effectiveness of the bonding role of the SEC regulation presents an empirical question rather than an established fact".
} 
regime. So while it is clear that the ADR holders are protected, although not to the same extent as those investors that hold U.S. firms, it is not altogether clear as to whether the holders of the firms' ordinary shares enjoy the same level of additional investor protection. In fact, Aggarwal, Dahiya, and Klapper (2005, p. 3) suggest that "ADR holders have better legal standing compared to holders of the underlying security as the ADRs are purchased in the U.S". We examine this issue further.

In order to examine whether cross-listing in the U.S. provides incremental protection for minority/ordinary shareholders, we follow the approach advocated by Benos and Weisbach (2004, p. 229). They argue that, given that regulatory bonding in the U.S. is unobservable to the researcher, "the issue of economic importance is whether managers and investors perceive cross-listings to have incremental protection or not. To examine this proposition, the appropriate approach is not to count SEC actions and debate whether they are important or not. Rather it is to examine the data for empirical implications of the hypothesis that cross-listings provide incremental protection, and therefore serve as a device enabling managers of non-U.S. firms to commit to protect the interests of their minority shareholders".

We examine the ordinary dividend payout of cross-listed firms around a cross-listing in the U.S. Our choice of variable is motivated by the fact that (1) dividend payout is increasing in the level of investor protection (e.g., LaPorta, Lopez-de-Silanes, Shleifer, \& Vishny, 2000, hereafter LLSV) and, consequently (2) changes in external investor protection are associated with changes in firm dividend payout (e.g., Liu, 2002), controlling for firm, industry and country level determinants of dividend payout. In addition, our choice of dependent variable is motivated by our desire to isolate the impact of cross-listing on the domestic/ordinary shareholders (as against the ADR shareholders) of cross-listed firms. We employ the ordinary dividend payout of firms to achieve this goal. The agency models of dividends do not rely on specific rights per se, but rest on the premise that country laws and/or governance practices allow minority shareholders greater rights in general. We argue that firms may only be reluctant to pay lower dividends if they perceive that their minority investors will accept lower dividends for improvements in investor protection, as dividend cuts are costly. Minority/ordinary shareholders are more likely to accept lower dividends post-listing if they are compensated for reduced dividends with enhanced protection from listing in the U.S. Easterbrook (1984) outlined how governance practices and dividends are substitutes for one another. We argue that the additional protection afforded to minority investors from listing in the U.S. derive not only from additional general rights per se, but also from a reduced ability of controlling insiders to consume private benefits (e.g., Barzuza, 2005; Doidge, 2004; Doidge, Karolyi, Lins, Miller, \& Stulz, 2005).

Using a sample of 496 cross-listed firms from forty countries we find that exchange-listed firms pay significantly lower dividends, post-listing, and this finding is robust to the inclusion of firm, industry and country controls. ${ }^{3}$ This result is consistent with the notion that these investors are better protected under the U.S. regime. In line with our expectations we find no evidence suggesting that the ordinary shareholders of Rule 144a firms benefit from incremental protection, post-listing. Interestingly, our results suggest that the minority investors of Level 1 OTC firms are better protected. Although inconsistent with the legal bonding hypothesis, we show that these firms consistently establish a reputation for better protection of their investors by paying out a greater proportion of their earnings as dividends. Consequently, their ability to pay lower dividends

\footnotetext{
${ }^{3}$ We provide a detailed sample description in the working paper version of the paper. The working paper is available at the following address: www.nuim.ie/academic/economics.
} 
post-listing may well result from a voluntary commitment on the part of these firm to protect their investors that is credible given their reputation for fair treatment. In support of this argument we find that the firm-level governance of Level 1 OTC firms, as measured by the number of closely held shares improves in the post-listing period. We find no such effect for SEC Rule 144a traded firms.

Our results have also important implications for the agency models of dividends. We find support for both the outcome and substitution models of dividends. More specifically, we find that in all cross-sectional periods, and over the full sample period, dividend payouts are significantly higher in countries where minority investors enjoy greater legal protection. In addition, and in line with Liu (2002), Zhang (2005), and Hwang, Park, and Park (2004), we document support in favour of the substitute model of dividends: governance improvements substitute for dividends as a mechanism of controlling the agency costs associated with free cash flow. This finding is also consistent with the evidence that inter alia, improved governance helps explain why dividend payouts have been falling over time (e.g., DeAngelo, DeAngelo, \& Skinner, 2003; Fama \& French, 2002a). ${ }^{4}$ This of course suggests that the relation between dividend payouts and governance is non-constant and as such purely cross-sectional tests are biased towards acceptance of the outcome model of dividends. Our results suggest that both are not directly competing against one another.

\section{Cross-listing in the United States and the legal bonding hypothesis}

Non-U.S. firms can cross-list in the U.S., either directly as ordinary shares or as American Depositary Receipts. ${ }^{5}$ Other than Canadian and Israeli firms, the majority of non-U.S. firms list as ADRs. A sponsored, public Level 1 OTC depositary receipt program is the simplest way for nonU.S. firms to access U.S. and non-U.S. capital markets. They trade 'over-the-counter' and also on some exchanges outside of the U.S., with prices published on the "Pink Sheets". A Rule 144A depositary receipt program, established by the SEC in 1990 facilitates access to U.S. and non-U.S. markets through a private placement of sponsored depositary receipts to Qualified Institutional Buyers. Trades are executed under the Portal system, and cleared through the Depositary Receipt Trust. Like Level 1 ADRs, they do not require compliance with U.S. G.A.A.P. or SEC registration. Under Regulation S, a company can offer a depositary receipt program to non-U.S. investors on Designated Offshore Securities Markets 'DOSM'. Unlike Level 1 OTC or SEC Rule 144a Portal ADRs, cross-listing in the U.S. via a Level 2/3 exchange-listed ADR (or a direct listing on a U.S. exchange or NASDAQ) obligates these firms to provide fuller disclosures under U.S. G.A.A.P., and operate under the mantra of the Securities and Exchange Commission (SEC), thus becoming subject to their enforcement powers. Furthermore, cross-listing in the U.S. also affords minority investors the means to exercise effective and low-cost legal remedies, unavailable at home, and exposes the firms to what Coffee (2002) terms "Reputational Intermediaries": underwriters (in the case of Level 3 capital-raising firms), financial analysts, auditors and bond rating agencies. The extant literature has documented how each can play a vital role in monitoring firms, facilitating the production of firm-specific private information into public information (see Lang, Lins, \& Miller,

\footnotetext{
${ }^{4}$ Interestingly, Ikenberry and Julio (2004) document a rebound in this trend. They show that since 2000 the proportion of U.S. firms paying cash dividends has increased and relate much of this shift to the maturity hypothesis.

5 Dutch companies trade largely as New York Shares (NYS) in the United States. New York Shares (NYS) offer many of the benefits of Depositary Receipts but they are less efficient in terms of cross-border settlement, and in their registration process.
} 
2002). The legal bonding hypothesis outlines how such additional disclosures and monitoring allows firms to effectively 'rent' the U.S. governance regime by listing on a U.S. exchange. Unlike exchange-level ADRs, Level 1 OTC and Portal level ADRs are not required to become "reporting companies" under the U.S. disclosure and regulatory environment (e.g., Coffee, 2002). Accordingly, the incremental protection benefits that accrue to the shareholders of cross-listing firms, if they do exist, apply only to exchange-listed ADRs. The different ADR classifications are outlined in Appendix A.

\section{Data and summary statistics}

We begin our study by obtaining a complete list of depositary receipts from The Bank of New York (www.adrbny.com) and cross-reference this list with additional data sourced from Deutsche Bank (www.adr.db.com), JP Morgan (www.adr.com) and Citibank (wwss.citissb.com/adr). From each we were able to obtain the names, listing dates, the firms' country of origin, the type of depositary receipt (Level 1 OTC, Level 2/3 Exchange (NYSE, Nasdaq, AMEX), Portal Rule 144a) as of July 2003. We also sourced a list of direct listings, for which the legal requirements of cross-listing are essentially the same as those for exchange-listed ADRs from the official website of the NYSE and NASDAQ. Supplementary data is sourced from the Over the Counter Bulletin Board (OTCBB), the New York Stock Exchange (NYSE) and the NASDAQ. For firms with joint and simultaneous DR listings (OTC/Portal Programs) we classify these firms as Level 1 OTC programs. If a firm has multiple DR programs, with different start dates, we classify this firm according to its earliest DR program, and ignore any subsequent programs. Finally, we include only those firms with sponsored DR programs; firms that voluntarily trade as ADRs in the U.S.

To be included in our final sample we imposed the following preconditions: (1) We only include those firms for which data relating to both variants of our dependent variable is available (2) We exclude those firms with either, missing (entirely) pre or post-listing dividend payout data. This 'Narrow' sample approach is necessary to ensure that any conclusions that we make are not due to a significant change in our sample makeup around the cross-listing data. We obtained our non-cross listed sample from the country lists provided by Datastream. From the country lists, we exclude all firms with a U.S. listing, and include only those firms in our sample with data available on all our control variables. (3) Like Liu (2002), but unlike La Porta et al. (2000) we include those firms from countries with mandatory dividend requirements. As a result, we include firms from Brazil, Chile, Colombia, and Greece and finally, (4) we exclude all financial firms (firms with SIC beginning with 6). We also placed the following data restrictions on both samples (both versions of our dependent variable): (I) we exclude observations due to probable data errors; negative net sales or revenues, negative market-to-book assets, and negative dividends paid. (II) In common with La Porta et al. (2000), and Liu (2002), we eliminate possible outliers in our dependent variable(s) by removing the top $1 \%$ of outliers. (III) Due to possible errors in scaling the data with net sale or revenues, we also eliminate outliers from each of our covariates by eliminating the top and bottom $1 \%$ of observations.

After imposing these requirements, our final sample is comprised of 3418 firms from 40 countries: 496 of which are either firms trading in the U.S. as ADRs or listed directly on U.S. Exchanges, the remaining 2922 are non cross-listed firms. Our non-cross-listed sample is dominated by a combination of firms from Brazil (7.60\%), Japan $(23.41 \%)$ and the United Kingdom $(11.02 \%)$. On the other hand, 18 countries contribute less than $1 \%$ each of our non-cross-listed sample. The majority of Level 1 ADRs are supplied by firms from Hong Kong (13.25\%), the United Kingdom (11.54\%), Australia (5.98\%), Brazil (5.56\%), India (5.56\%) and South Africa 
Table 1

Dividend payout levels by ADR classification (mean (median))

\begin{tabular}{|c|c|c|c|c|}
\hline & Non-cross list & Level 1 & Level 2/3 & Rule $144 a$ \\
\hline \multicolumn{5}{|l|}{ Dividends-to-earnings } \\
\hline Full sample & $38.00(30.29)$ & $35.92(32.98)$ & $32.20(25.31)$ & $34.64(27.56)$ \\
\hline Low anti-director & $35.55(29.84)$ & $31.73(30.94)$ & $32.89(31.35)$ & $33.48(18.25)$ \\
\hline High anti-director & $39.05(30.53)$ & $35.92(32.85)$ & $31.61(22.56)$ & $32.17(23.62)$ \\
\hline \multicolumn{5}{|l|}{ Dividends-to-cashflow } \\
\hline Full sample & $20.42(14.21)$ & $20.22(18.34)$ & $16.14(11.89)$ & $17.69(13.00)$ \\
\hline Low anti-director & $16.46(11.69)$ & $14.95(13.13)$ & $13.88(12.22)$ & $8.28(5.46)$ \\
\hline High anti-director & $21.66(14.93)$ & $20.84(18.23)$ & $16.42(11.31)$ & $18.54(13.90)$ \\
\hline \multicolumn{5}{|c|}{ Significance tests (high vs. low) } \\
\hline \multicolumn{5}{|c|}{ Dividends-to-earnings } \\
\hline Mean & $-3.23^{* * *}$ & $-2.54^{* *}$ & 0.42 & 0.0215 \\
\hline Median & $-6.93^{* * *}$ & $-2.22^{* *}$ & $2.73^{* * *}$ & -0.554 \\
\hline \multicolumn{5}{|c|}{ Dividends-to-cashflow } \\
\hline Mean & $-15.88^{* * *}$ & $-8.89^{* * *}$ & $-4.61^{* * *}$ & $-3.87^{* * *}$ \\
\hline Median & $-16.26^{* * *}$ & $-6.94^{* * *}$ & -0.765 & $-4.43^{* * *}$ \\
\hline
\end{tabular}

In this table we report mean and median dividend payout levels for non-cross-listed firms and cross-listed firms over the full sample period. Dividends-to-cashflow and dividends-to-earnings are employed as our payout proxy. Both are defined in the appendix. Dividend payouts for all cross-listed firms are calculated over the full sample period for each firm which includes both the pre and post-listing period. For both cross-listed and non-cross-listed firms we report both $t$ - and $Z$-stats for the mean and median difference between high and low investor protection countries, respectively.

** Significance at the $5 \%$ level.

*** Significance at the $1 \%$ level.

(5.13\%). Our exchange-listed Level 2/3 ADR sub-sample is dominated by firms from the U.K. (20.69\%), followed by France and Japan with $6.90 \%$ each. Non-surprisingly, the vast majority of direct listings in the U.S. are Canadian firms (97.37\%). Finally, India (26.00\%) and Taiwan $(20.00 \%)$ make up the majority of firms that trade on the Portal under SEC Rule 144a.

We begin by outlining some summary payout measures for both cross-listed and non-crosslisted firms. The results are outlined in Table 1. For both variants of our dependent variable, we calculate both mean and median payout ratios over the full sample period. We outline summary measures for all cross-listed and non-cross-listed firms, and then further sub-divide the representative categories into firms originating from both high and low investor protection countries. As before, firms are characterised as either high or low investor protection firms according to their countries anti-directors right index.

The most striking result from Table 1 is that Level 1 OTC firm's payout a higher percentage of their earnings as dividends than both exchange-listed and Rule 144a firms. ${ }^{6}$ Second, our sample of non-cross-listed firms also pays our more dividends than both exchange-listed firms and Rule 144a firms, but pay slightly less (in terms of median payout) than Level 1 OTC firms. These results

\footnotetext{
${ }^{6}$ In the working paper, we show that this relation holds in both the pre and post-listing periods. More specifically, we find that of the 30 countries with Level 1 OTC listings, exactly half pay lower dividends, post-listing (15/30), 40\% pay higher dividends (12/30), and 10\% remain unchanged (3/30). For exchange-listed ADRs, we find that of the 28 countries with Level 2/3 ADRs, 57\% (16/28) pay lower dividends post-listing, 11 of the 28 pay higher dividends and 1 remain unaltered. Finally, for Rule 144a firms, 10 of 19 pay higher dividends; while 9/19 pay lower dividends, post-listing. The results using dividend-to-cashflow mirror those of dividend-to-earnings.
} 


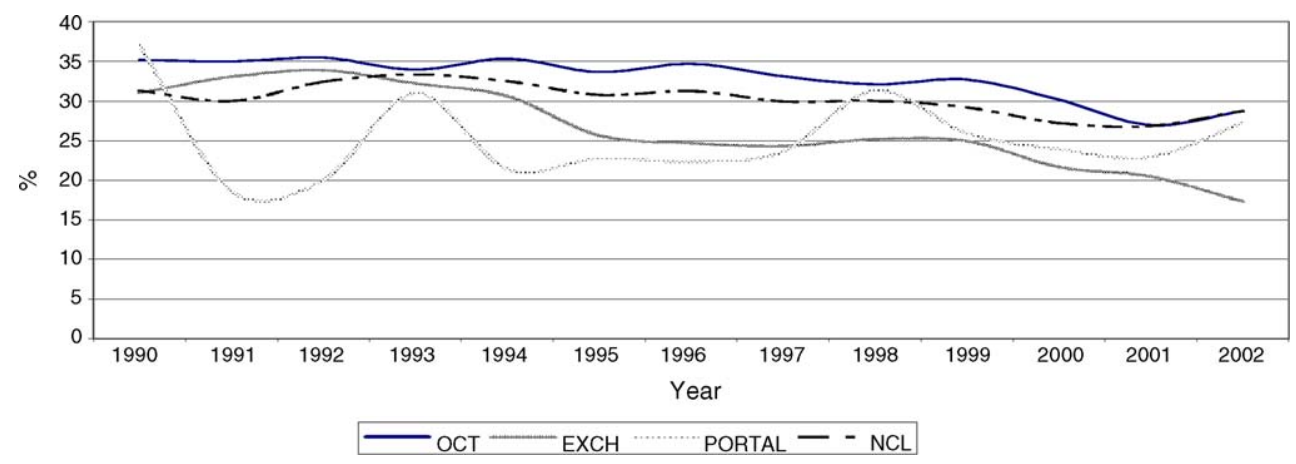

Fig. 1. Median dividends-to-earnings (\%) for OTC, EXCH, PORTAL and NCL firms.

are replicated when dividends-to-cashflow is employed as our dependent variable. Interestingly, the earlier relations are largely replicated for Level 1, Level 2/3, and Rule 144a firms from both high and low investor protection countries. The results for low investor countries are especially interesting. They suggest that Level 1 OTC firms pay higher dividends than both exchange-listed and Rule 144a firms. This result may be driven by anti-directors rights measure differences within the low investor protection class or it may point to a relation between firm-level governance and dividend payout. To examine this issue further we plot the time series behaviour of dividendpayout for cross-listed and non-cross-listed firms over the full sample period. The results are reported in Figs. 1-12. In Figs. 1 and 2 we outline the time-series behaviour of dividend-payout by ADR level. In the remaining figures we classify cross-listed firms according to both their ADR level and their countries level of investor protection. The figures suggest that the findings from Table 1 are largely replicated in each cross-section. For example, in almost every year, dividend payouts are greater in those countries where investors are better protected. When we separate firms by ADR level, we show that this relationship is unaffected. Finally, our earlier findings for Level 1 OTC firms are replicated in Figs. 4-7 and 10. As before, both Level 1 OTC firms from high and low investor protection countries pay significantly higher dividends than their exchangelisted and Portal counterparts. Our finding that dividend payout is increasing in investor protection is consistent with the findings of LLSV (2000). In addition, we show that this relationship has persisted over time. In the next section we test the agency models of dividends in a dynamic setting by, allowing investor protection to change for at least a subset of our sample, i.e. for Level

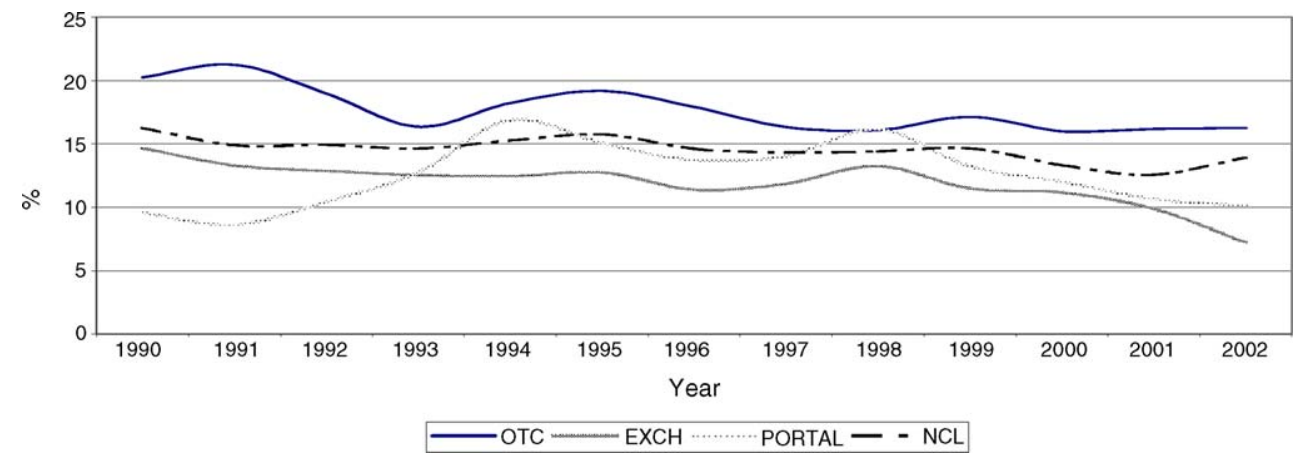

Fig. 2. Median dividends-to-cashflow (\%) for OTC, EXCH, PORTAL and NCL firms. 


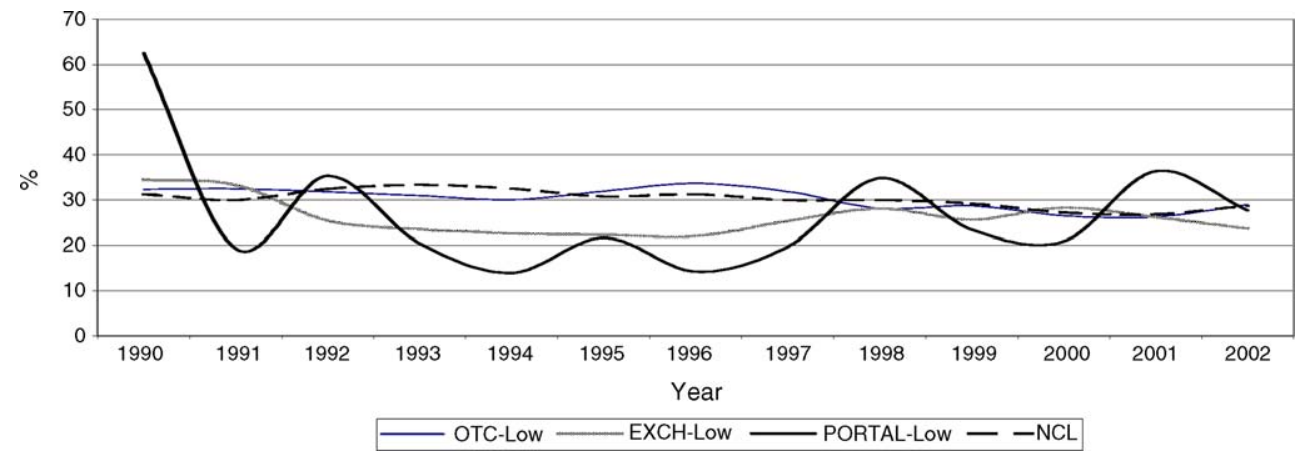

Fig. 3. Median dividends-to-earnings (\%) for low IP OTC, EXCH, PORTAL and NCL.

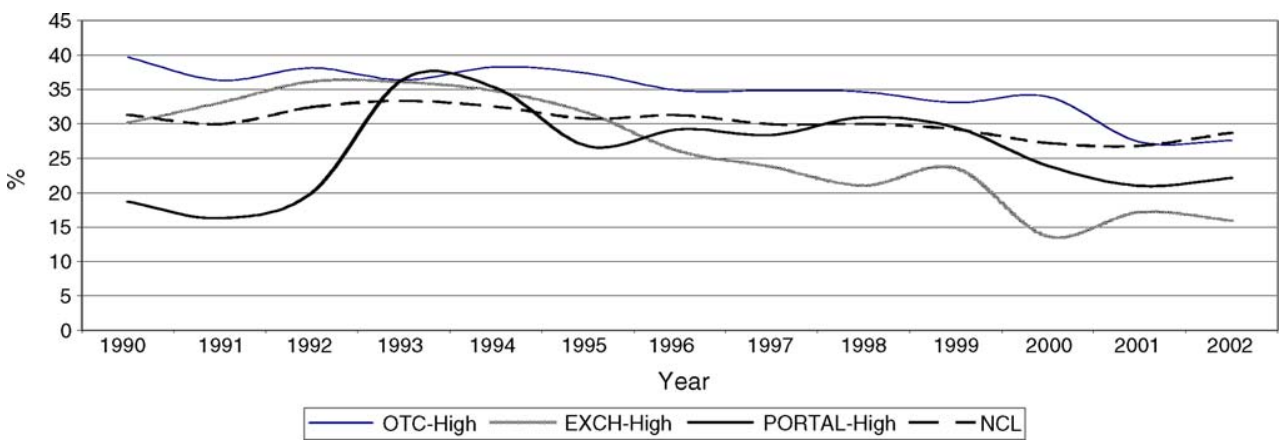

Fig. 4. Median dividends-to-earnings (\%) for high IP OTC, EXCH, PORTAL and NCL.

$2 / 3$ cross-listed firms. We hypothesise that if cross-listing in the U.S. is associated with enhanced protection for the domestic investors of Level 2/3 listed firms, we should observe a change in ordinary dividend payout.

\section{Econometric specification}

In the following section we outline the empirical methodology employed in the paper. In all regressions we compare the change in ordinary dividend payout for cross-listed firms relative to

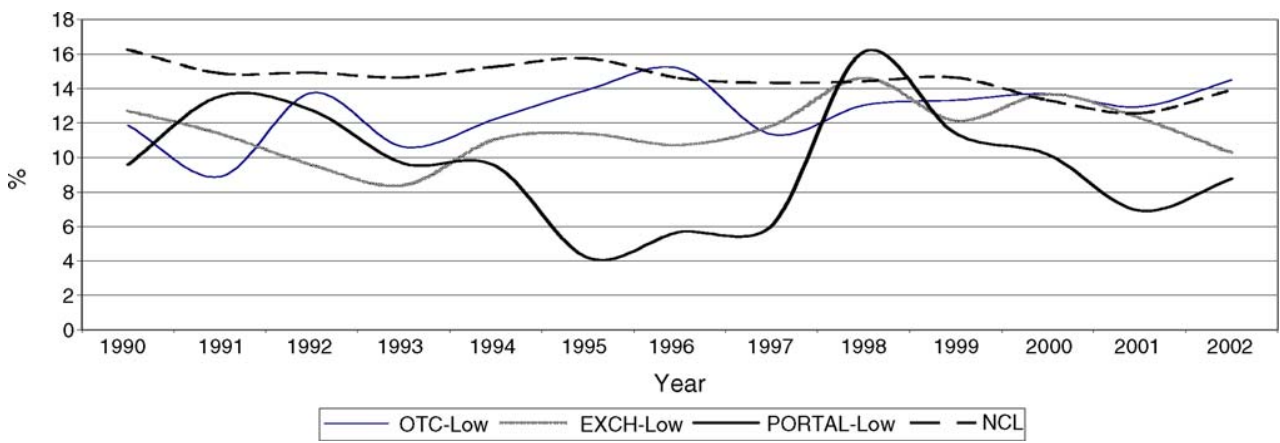

Fig. 5. Median dividends-to-cashflow (\%) for low IP OTC, EXCH, PORTAL and NCL. 


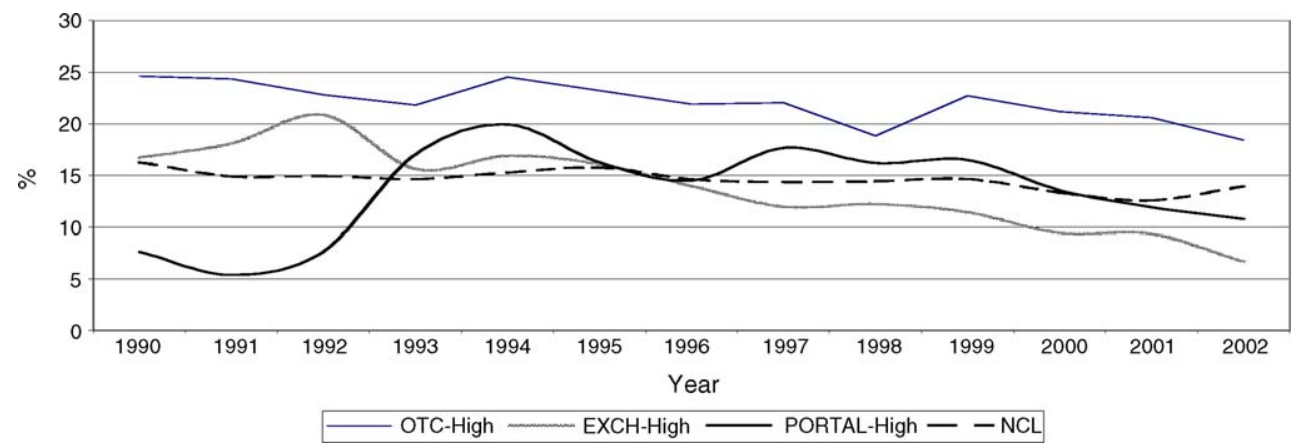

Fig. 6. Median dividends- to-cashflow (\%) for high IP OTC, EXCH, PORTAL and NCL.

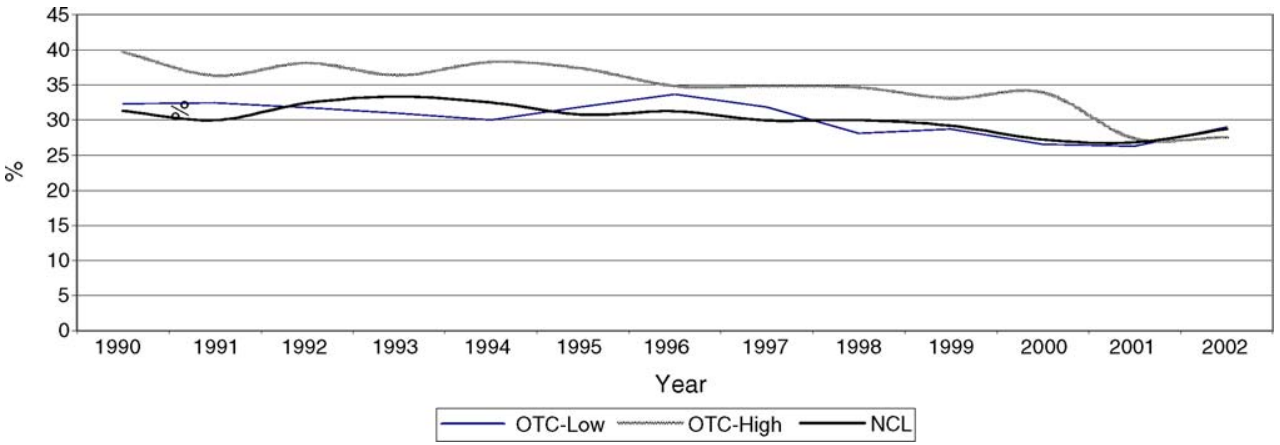

Fig. 7. Median dividends-to-earnings (\%) for OTC firms (low and high IP) and NCL.

non-cross-listed firms around the cross-listing date. This is motivated by the fact that regulatory bonding in the U.S. is unobservable to the researcher. By examining the changes in ordinary dividend payout, we seek to (1) isolate the impact of cross-listing 'around' the time of cross-listing by controlling for firm, industry and country level determinants of ordinary dividend payout; (2) allow this effect to vary across the different listing types (Level 1 OTC, Level 2/3 Exchange lists, and SEC Rule 144a Portal ADRs) using a simple dummy variable specification; and (3) use this change in dividend payments made to ordinary shareholders to make inferences about how domestic investor protection has changed, post-listing.

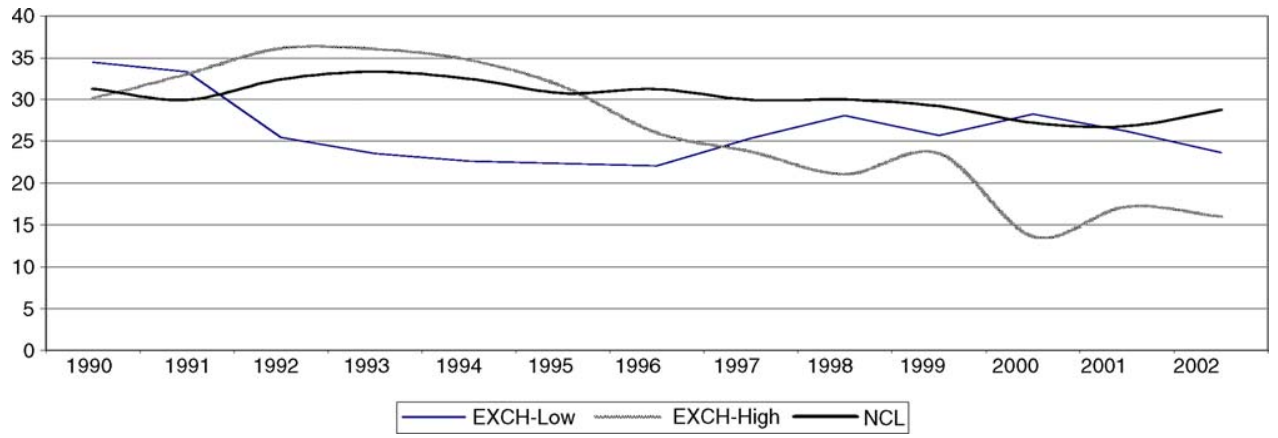

Fig. 8. Median dividends-to-earnings (\%) for EXCH firms (low and high IP) and NCL. 


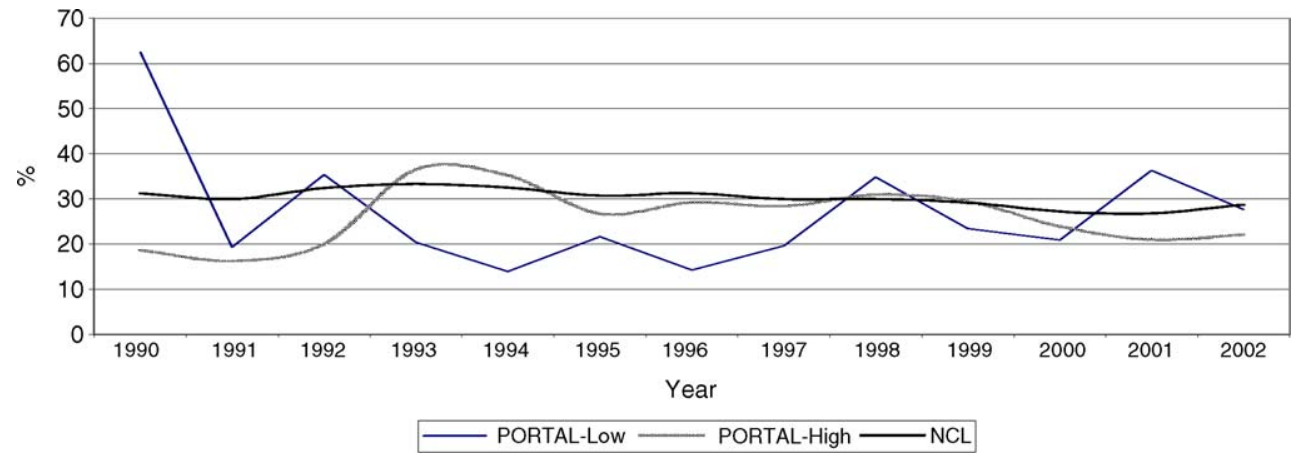

Fig. 9. Median dividends-to-earnings (\%) for PORTAL firms (high and low IP) and NCL.

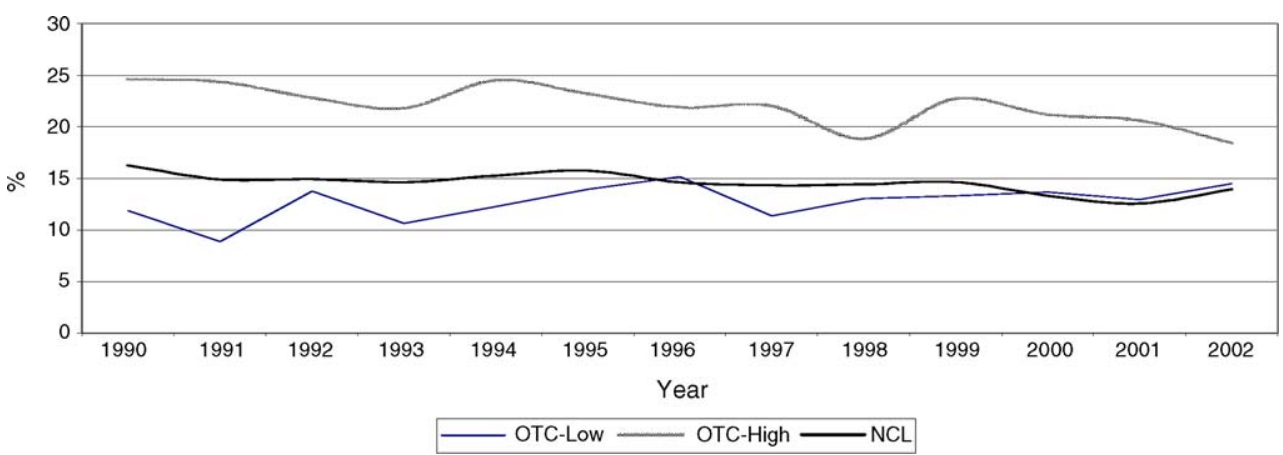

Fig. 10. Median dividends-to-cashflow (\%) for OTC firms (high and low IP) and NCL.

To estimate the effect of cross-listing on the ordinary dividend payout of firms, the following regression specification is followed:

$$
\begin{aligned}
& \operatorname{div}_{i t}=\alpha+X_{i t} \beta_{1}+\delta_{1} \mathrm{OTC}_{i t}+\delta_{2} \mathrm{EXCH}_{i t}+\delta_{3} \mathrm{PORTAL}_{i t}+\alpha_{t}+\alpha_{i}+v_{i t} \\
& \operatorname{div}_{i t}=\alpha+X_{i t} \beta_{1}+\delta_{1} \mathrm{OTCAD}_{i t}+\delta_{2} \mathrm{EXCH} \mathrm{AD}_{i t}+\delta_{3} \mathrm{PORTAL} \mathrm{AD}_{i t}+\alpha_{t}+\alpha_{i}+v_{i t}
\end{aligned}
$$

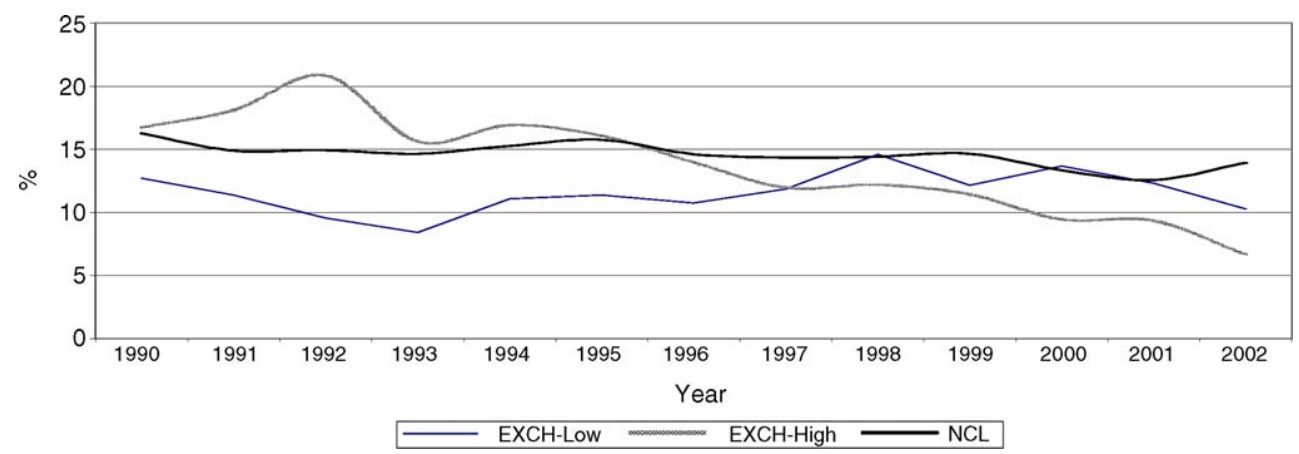

Fig. 11. Median dividends-to-cashflow (\%) for EXCH firms (high and low IP) and NCL. 


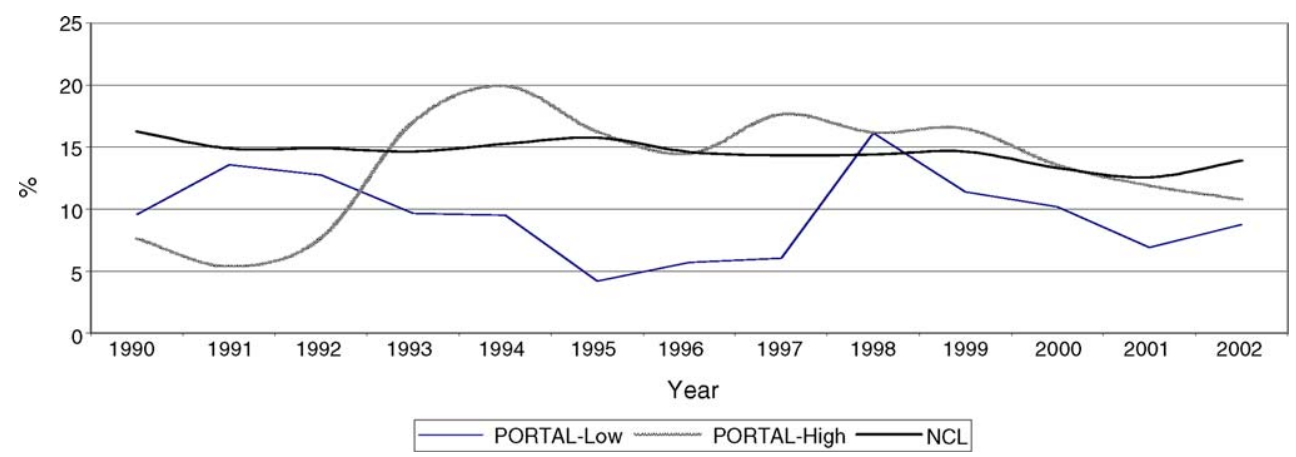

Fig. 12. Median dividends-to-cashflow (\%) for PORTAL firms (high and low IP) and NCL.

where $\operatorname{div}_{i t}$ is the ordinary dividend payout of firm $i$ in year $t$. To ensure that our results are not specific to our definition of firm dividend payout, we employ two different measures of ordinary dividend payout. First, we employ the traditional measure of dividend payout, dividends to earnings. (Div/Earn $)_{i t}$ is defined ((dividends per share/earnings per share $\left.) \times 100\right)$. Our second measure, dividends-to-cashflow (Div/CF) $)_{i t}$ is defined similarly. $\mathrm{OTC}_{i t}, \mathrm{EXCH}_{i t}$ and $\mathrm{PORTAL}_{i t}$ are dummy variables that identify whether an individual firm $i$ is cross-listed in the United States at time $t$ either as a Level 1 OTC, Level 2/3 Exchange-listed ADR, or under SEC Rule 144a on Portal. $\delta_{1}, \delta_{2}, \delta_{3}$ are parameters to be estimated. In the two-way fixed effects specification (Eq. (1)), these parameters estimate the 'causal' effect of cross-listing on ordinary dividend payout within firms that change from not-listing to listing, i.e. the within estimates. $X_{i t}$ is a vector of time-varying firm and time-invariant country level variables (rather than include country fixed effects). $\alpha_{t}$ are time fixed effects, and $v_{i t}$ is a standard idiosyncratic disturbance term. In Eq. (2), we include interaction variables where we interact the ADR dummy variables with the anti-director rights measure provided by LLSV (1998). In our specification, AD is 1 if the firm originates in a country where investors are poorly protected (anti directors rights $<3$ ). This specification allows us to measure the governance effects of cross-listing for firms from countries where the protection afforded to investors is poor. ${ }^{7}$ A priori, the sign of the coefficients $\delta_{1}, \delta_{2}, \delta_{3}$ and their significance are ambiguous. Although we believe that the coefficients on OTC, Portal should be insignificant in line with the predictions of the legal bonding hypothesis, the coefficient for exchange-listed firms is less clear. The reasoning is as follows: given the considerable underdevelopment of legal institutions in some countries (see LLSV, 1998), the prevailing wisdom suggests that the incremental investor protections from listing in the U.S. should thus on theoretical grounds be greater for these firms. On the other hand, Doidge, Karolyi, and Stulz (2004b) outline a theoretical model and provide empirical support in favour of the notion that country and firm governance are complementary to one another. As such, voluntary firm governance improvements are more effective in countries where country governance is already effective. Mitton (2004) using a sample of emerging market firms, finds additional support in favour of this proposition. Thus, the incremental governance benefits of listing in the U.S. for 'emerging market' firms may not be as effective due to poor governance at home. $\alpha_{i}$ is unobserved firm level heterogeneity. We test whether these effects should

\footnotetext{
${ }^{7}$ Our results are largely unaffected when we include the anti-director rights measure for each firm (measured at the country level), rather than the binary variable approach adopted. The anti-director rights measure ranges from 1 to 6.
} 
be treated as fixed or random by employing the standard Hausman (1978) test. The results (along with the Mundlak (1978) test) suggest that both the $X_{i t}$ and $\alpha_{i}$ are correlated, i.e. $\operatorname{Cov}\left(X_{i t} \alpha_{i}\right) \neq 0$. Consequently, we estimate a two-way fixed effects model outlined in Eqs. (1) and (2). Tests adopted from Baum (2001), Drukker (2003) and Wiggins (2003) suggest that the idiosyncratic errors are not independent and identically distributed. Consequently in all specifications, our reported standard errors are robust to both heteroscedasticity and arbitrary within-group correlation using Rogers (1993) standard errors clustered by firm. In addition to the tests outlined we also test for the presence of 'Firm' and 'Time' effects in the residuals by using the intuitive approach outlined in Petersen (2005). These results suggest that in line with our prior expectations, the error term contains a large firm effect, but a smaller time effect which is common in corporate finance panel data sets. In the presence of such Petersen (2005) advocates the superiority of using Rogers (1993) standard errors clustered by firm, given the inclusion of fixed time effects $\left(\alpha_{t}\right)^{8}$

In our second empirical specification, we use a Tobit model to control for data censoring given that dividend payout is left censored at zero. The results of the Hausman (1978) test outlined in the previous paragraph suggest that the individual specific effects are correlated with the regressors. Unlike the fixed effects model, it is impossible within the Tobit specification to eliminate the $\alpha_{i}$ by differencing them out. Furthermore, the unobserved effects cannot be conditioned out of maximum likelihood. Consequently, there exists no fixed effects Tobit model. In order to overcome this we adopt the approach of Wooldridge (2002). He shows that one can use a general Chamberlain (1984) style model by specifying the unobserved heterogeneity as a function of firm level means of included regressors, as specified by Mundlak (1978) so:

$\alpha_{i}=\bar{X}_{i} \zeta+a_{i}$ where $\bar{X}_{i}=(1 / T) \sum_{s=1}^{T} X_{i t}$. The mean of time-invariant regressors are excluded. The firm level means are substituted into Eqs. (1) and (2) yielding the following:

$$
\begin{aligned}
& \operatorname{div}_{i t}=\alpha+X_{i t} \beta_{1}+\delta_{1} \text { OTC }_{i t}+\delta_{2} \mathrm{EXCH}_{i t}+\delta_{3} \text { PORTAL }_{i t}+\bar{X}_{i} \xi+v_{i t} \zeta \\
& \operatorname{div}_{i t}=\alpha+X_{i t} \beta_{1}+\delta_{1} \mathrm{OTCAD}_{i t}+\delta_{2} \mathrm{EXCH} \mathrm{AD}_{i t}+\delta_{3} \mathrm{PORTALAD}_{i t}+\bar{X}_{i} \zeta+v_{i t}
\end{aligned}
$$

Eqs. (3) and (4) are estimated using Pooled Tobit (e.g., Wooldridge, 2002). In all specifications the regression standard errors are robust to non-normality, heteroscedasticity and arbitrary within-group correlation (e.g., Hardin (2005)). We present results for the Pooled Tobit model in Tables 2 and 3 and use the fixed effects estimates (unreported) to validate the results we report for the Pooled Tobit model.

Our firm level controls, $X_{i t}$ includes the following: (1) Firms Investment Opportunity Set (Market to Book Value of Assets) (e.g., Rozeff, 1982) (2) Profitability of Assets in place (ROE).

Return on Equity is calculated as earnings per share divided by book growth per share (3) Firm Size (Total Assets (Log)) (4) Free Cash Flow (FCF), (e.g., Jensen, 1986) (5) Operating and Financial Leverage (Cost of Goods Sold (COGS) and Debt), (e.g., Fazzari et al., 1988) and (6) Earnings Volatility (EPS) (e.g., Fama and French, 2002a, 2002b) is calculated as the variance of the previous three years earnings per share. To conserve space, in Tables 2 and 3 we present results using only MBA, size and profitability as firm-level controls. The results are not affected

\footnotetext{
${ }^{8}$ Absent appropriate adjustment of the standard errors, we show in the working paper that the standard errors are consistently underestimated by as much as $200 \%$ for some of the regressors.
} 
Table 2

Pooled Tobit analysis of dividend policy of cross-listed firms

\begin{tabular}{|c|c|c|c|c|c|c|c|c|c|}
\hline \multirow[t]{2}{*}{ Variable } & \multirow[t]{2}{*}{ Sign } & \multicolumn{8}{|l|}{ Pooled Tobit } \\
\hline & & (1) & $\mathrm{d} y / \mathrm{d} x$ & (2) & $\mathrm{d} y / \mathrm{d} x$ & (3) & $\mathrm{d} y / \mathrm{d} x$ & (4) & $\mathrm{d} y / \mathrm{d} x$ \\
\hline OTC & \pm & $-1.22(-0.59)$ & -0.6742 & $-9.28(-4.2)^{* * *}$ & -5.12 & $-9.25(-4.2)^{* * *}$ & -5.10 & $-10.57(-4.8)^{* * *}$ & -5.79 \\
\hline $\mathrm{EXCH}$ & \pm & $-7.38(-2.4)^{* *}$ & -3.93 & $-19.96(-5.4)^{* * *}$ & -10.32 & $-19.84(-5.3)^{* * *}$ & -10.27 & $-20.07(-5.5)^{* * *}$ & -10.38 \\
\hline PORTAL & \pm & $-0.78(-0.15)$ & -0.43 & $-8.16(-1.56)$ & -4.51 & $-8.61(-1.60)$ & -4.74 & $-9.15(-1.71)^{*}$ & -5.03 \\
\hline Intercept & & $24.56(5.44)^{* * * *}$ & & $-41.37(-10)^{* * *}$ & - & $-44.17(-5.3)^{* * *}$ & - & $-45.86(-5.6)^{* * *}$ & - \\
\hline MBA & - & - & & $-0.67(-4.3)^{* * *}$ & -0.39 & $-0.67(-4.3)^{* * *}$ & -0.38 & $-0.69(-4.4)^{* * *}$ & -0.40 \\
\hline ROE & + & - & & $0.06(2.1)^{* *}$ & 0.036 & $0.06(2.1)^{* *}$ & 0.037 & $0.06(2.2)^{* *}$ & 0.032 \\
\hline Log (total asset) & + & - & & $6.32(4.55)^{* * *}$ & 3.66 & $6.29(6.46)^{* * *}$ & 3.65 & $6.12(6.38)^{* * *}$ & 3.58 \\
\hline ADR dividend & \pm & - & & $16.71(5.4)^{* * *}$ & 10.65 & $16.59(5.26)^{* * *}$ & 10.56 & $16.85(5.38)^{* * *}$ & 10.75 \\
\hline Anti-director & + & - & & - & - & $5.63(3.77)^{* * *}$ & 3.19 & - & - \\
\hline Common law & + & - & & - & - & - & - & $5.65(4.28)^{* * * *}$ & 3.32 \\
\hline Industry effects & & Yes & & Yes & - & Yes & - & Yes & - \\
\hline Time effects & & No & & No & - & No & - & No & - \\
\hline Observations & & 29691 & & 21116 & - & 21116 & - & 21116 & - \\
\hline Censored Obs & & 5541 & & 3312 & - & 3312 & - & 3312 & - \\
\hline Log likelihood & & -131195 & & -94759 & - & -94734 & - & -94724 & - \\
\hline
\end{tabular}

In this table we report Pooled Tobit coefficient and marginal effects estimates of the effect of cross-listing on the ordinary dividend payouts of cross-listed firms around the cross-listing date. The final sample is comprised of 496 cross-listed firms and 2922 non-cross-listed firms from 40 countries over the period from 1990 to 2002 . Firm-level controls are sourced from both Worldscope and Datastream and are defined in the appendix. Country controls are also defined in the appendix. In each specification we report results for firms trading in the U.S. either Over-the-Counter (OTC) as a Level 1 ADR, a Level 2/3 Exchange-Listed ADR (EXCH), or on the Portal under Rule 144a (PORTAL). The Pooled Tobit standard errors are robust to non-normality and heteroscedasticity in the errors and are also clustered by firm to account for arbitrary within-group correlations. $Z$-stats reported for the Pooled Tobit. In columns 1-4 we include but do not report the estimates of the firm level means. In all but one specification, an $F$-test suggests that they are jointly significant at the $1 \%$ level. The marginal effects are calculated at the mean of the independent variables. For the dummy variables the marginal effects is calculated as the discrete change in $F(x)$ as the dummy variable $x$ changes from 0 to 1 .

* Significance at the $10 \%$ level.

** Significance at the $5 \%$ level.

*** Significance at the $1 \%$ level. 
Table 3

Tobit analysis of dividend policy of cross-listed firms by legal origin

\begin{tabular}{|c|c|c|c|c|c|c|c|c|c|}
\hline \multirow[t]{2}{*}{ Variable } & \multirow[t]{2}{*}{ Sign } & \multicolumn{8}{|l|}{ Pooled Tobit } \\
\hline & & (1) & $\mathrm{d} y / \mathrm{d} x$ & (2) & $\mathrm{d} y / \mathrm{d} x$ & (3) & $\mathrm{d} y / \mathrm{d} x$ & (4) & $\mathrm{d} y / \mathrm{d} x$ \\
\hline OTC AD & \pm & $-5.60(-1.31)$ & -3.01 & $-11.11(-2.47)^{* * *}$ & -6.03 & $-7.11(-1.53)$ & -3.95 & $-10.37(-2.2)^{* *}$ & -5.66 \\
\hline EXCH AD & \pm & $-6.45(-1.22)$ & -3.44 & $-22.42(-3.2)^{* * * *}$ & -11.34 & $-18.41(-2.6)^{* * * *}$ & -9.54 & $-21.09(-3.0)^{* * * *}$ & -10.76 \\
\hline PORTAL AD & \pm & $8.62(0.74)$ & 4.90 & $1.03(0.16)$ & 0.60 & $4.96(0.77)$ & 2.97 & $1.99(0.342)$ & 1.17 \\
\hline Intercept & & $25.38(5.63)^{* * *}$ & & $-20.30(-4.6)^{* * * *}$ & - & $-22.27(-0.82)$ & - & $-25.91(-0.95)$ & - \\
\hline MBA & _- & & - & $-0.66(-4.3)^{* * * *}$ & -0.39 & $-0.66(-4.2)^{* * * *}$ & -0.39 & $-0.68(-4.3)^{* * * *}$ & -0.39 \\
\hline ROE & + & & - & $0.06(2.04)^{* *}$ & 0.035 & $0.06(2.3)^{* *}$ & 0.035 & $0.06(2.3)^{* * *}$ & 0.032 \\
\hline Log (total asset) & + & & - & $5.65(5.84)^{* * * *}$ & 3.28 & $5.63(5.81)^{* * * *}$ & 3.27 & $5.51(5.71)^{* * * *}$ & 3.19 \\
\hline ADR dividend & \pm & & - & $8.48(2.85)^{* * *}$ & 5.16 & $7.85(2.63)^{* * * *}$ & 4.76 & $7.76(2.63)^{* *}$ & 4.71 \\
\hline Anti-director & + & & - & - & - & $4.71(3.02)^{* * * *}$ & 2.68 & - & - \\
\hline Common law & + & & - & - & - & _- & _- & $4.85(3.69)^{* * * *}$ & 2.84 \\
\hline Industry effects & & Yes & - & Yes & - & Yes & - & Yes & \\
\hline Time effects & & No & & No & - & No & - & No & \\
\hline Observations & & 29691 & - & 21116 & - & 21116 & - & 21116 & \\
\hline Censored Obs & & 5541 & & 3312 & - & 3312 & - & 3312 & \\
\hline Log likelihood & & -131210 & & -94820 & - & -94804 & - & -94794 & \\
\hline
\end{tabular}

In this table we report Pooled Tobit coefficient and marginal effects estimates of the effect of cross-listing on the ordinary dividend payouts of cross-listed firms around the cross-listing date. The final sample is comprised of 496 cross-listed firms and 2922 non-cross-listed firms from 40 countries over the period from 1990 to 2002 . Firm-level controls are sourced from both Worldscope and Datastream and are defined in the appendix. Country controls are also defined in the appendix. In each specification we report results for firms trading in the U.S. either Over-the-Counter (OTC) as a Level 1 ADR, a Level 2/3 Exchange-Listed ADR (EXCH), or on the Portal under Rule 144a (PORTAL). In this specification we interact the ADR Dummies with an investor rights measure developed by LLSV (1998). The ADR measure is 1 if the firm is domiciled in a country where investors are poorly protected $(\mathrm{AD}<3)$. The Pooled Tobit standard errors are robust to non-normality and heteroscedasticity in the errors and are also clustered by firm to account for arbitrary within-group correlations. $Z$-stats reported for the Pooled Tobit. In columns 1-4 we include but do not report the estimates of the firm level means. In all but one specification, an $F$-test suggests that they are jointly significant at the $1 \%$ level. For the dummy variables the marginal effects is calculated as the discrete change in $F(x)$ as the dummy variable $x$ changes from 0 to 1 .

** Significance at the $5 \%$ level.

${ }^{* * *}$ Significance at the $1 \%$ level. 
when we include the remaining firm-level control variables. All variables are summarised in Appendix B.

In Appendix C, we outline correlation coefficients and deal explicitly with concerns relating to multicollinearity by computing variance inflation factors. The correlation coefficients are by and large of the correct size. For example, (Div/Earn) ${ }_{i t}$ is positively related to profitability (ROE) and size, and negatively related to both volatility of earnings and growth opportunities (MBA). Surprisingly, both (Div/Earn) $i t$ and (Div/CF) $)_{i t}$ are negatively related to free cash flow, although neither are significant. Finally, the small variance inflation factors suggest that multicollinearity is not a significant problem in our data set.

We employ two country dummies to control for variations in dividend payout across legal regimes: (1) A simple 0/1 dummy for legal origin; 1 if the country employs common law, and 0 if the firm adopts civil law (2) We also employ a second dummy that accounts for cross-country differences in investor protection; we classify those firms as firms from high investor protection countries if their anti-director score is equal to or greater than the median value of 3 (La Porta et al., 1998) and control for payout differences across industries by classifying each firm in our sample according to their primary standard industry classification code. ${ }^{9}$ We repeat our analysis by including American Depositary Receipt Dividends as a covariate in our equations. ADR dividends are ordinary share dividends paid to the holders of ADRs, converted to U.S. Dollars at the prevailing spot exchange rate. We have no prior beliefs on the sign of the coefficient. For example, cross-listed firms with a history of paying dividends may also be those to pay a dividend to their ADR shareholders. Furthermore, we find that the inclusion of ADR dividends does not alter our main conclusions. All ADR dividend data is sourced from The Bank of New York (www.adrbny.com). All variables employed in our empirical analysis are defined in Appendix B.

\section{Results}

In both Tables 2 and 3, we present the results that estimate the effect of cross-listing on the ordinary dividend payout of cross-listed firms. In Table 2 we present the Pooled Tobit results corresponding to equation 3 . In Table 3 , we employ interaction variables to assess the impact of cross-listing on the dividend payout of firms originating from countries where minority investors are poorly protected. In both tables, we outline regression results with the cross-listing dummies only (column 1), the cross-listing dummies with firm level controls (column 2), and in columns (3 and 4) we augment the ADR dummies and the firm level controls with country level governance variables. In column (3) and we employ the LLSV (1998) anti-director rights measure, and in column (4) we include a dummy variable corresponding to whether a firm is domiciled in a common law jurisdiction. Both variables are expected to impact positively on dividend payout (e.g., LLSV, 2000). All our findings are robust to the inclusion of dividends to cashflow as our dependent variable. In addition to reporting the coefficient estimates, we also report the marginal effects at the means of each variable. For the dummy variables the marginal effects are calculated as the discrete change in $F(x)$ as the dummy variable $x$ changes from 0 to 1 .

\footnotetext{
${ }^{9}$ Based on this classification we form seven industry dummies; (1) Agriculture, Fishing, and Forestry (2) Mining and Construction (3) Manufacturing (4) Transportation, Communications, Electric, Gas and Sanitary Services (5) Wholesale and retail trade (6) Services and (7) Public Administration. We exclude all finance, insurance, and real estate firms (SIC beginning with 6 ).
} 
We begin by outlining the results from Table 2 . The first major result from Table 2 is that exchange-listed firms pay significantly lower dividends, post-listing. This finding is robust to both the inclusion of both firm and country controls (and industry controls in the case of the Pooled Tobit model). This is important given that those firms that cross-list are very often those with sizable growth opportunities, proxied here by market to book of assets. We show that even after including this control, exchange-listed firms pay significantly lower dividends, post-listing. Thus our results are not driven by the sizable investment opportunity set of cross-listed firms. This result is in line with the results reported by Mitton (2004) for a sample of emerging market crosslisted firms and suggests that firms substitute dividends for improved firm-level governance. This result is also consistent with the findings of Liu (2002), who outlines how functional convergence measures initiated are associated with lower dividend payouts. Our finding for Level 2/3 listed firms suggest that rather than compete with one another, the outcome and substitute models of dividends are not mutually exclusive to one another. Rather, our results suggest a role for both in explaining the relationship between investor protection and firm dividend payout. Like Liu (2002), our results suggest that cross-sectional tests are biased towards an acceptance of the outcome model of dividends.

In all specifications, the country and firm level controls are highly significant and of the expected sign. For example, larger and profitable firms pay higher dividends, while firms with sizable growth opportunities retain a sizable amount of earnings, rather than pay dividends. In line with our expectations, firms from common law countries with efficient legal and institutional frameworks pay significantly higher dividends (see LLSV, 2000). Finally, we document that firms that pay an ADR dividend also pay larger dividends suggesting a possible clientele effect. In Table 3, we examine the impact of cross-listing on dividend policy for firms from countries with a poor record for protecting minority investors. Comparing Tables 2 and 3 the results suggest that although the magnitudes of the Tobit estimates are broadly similar, their significance is not as strong when compared to the same results in Table 2. This suggests that the benefits to listing may not be as great for firms from poor-investor protection countries, consistent with the notion that firm and country governance improvements are in fact complementary to one another.

The results for Rule 144a firms are consistent with theory. The results from both Tables 2 and 3 suggest that cross-listing in the U.S. confers no additional protection benefits for the ordinary shareholders of these firms. In almost all specifications Rule 144a firms do not significantly change the amount that they pay to their ordinary shareholders. Finally, the results that we report for Level 1 OTC firms are very interesting. We find in all regression specifications that these firms pay significantly lower dividends, post-listing, a result consistent with the notion that like exchange-listed firms, these firms substitute dividends for enhanced governance. However, this warrants further discussion. Level 1 OTC firms do not adhere to the U.S. legal and regulatory regime as Level 1 OTC firms are exempt from becoming 'reporting' companies under the terms of the Level 1 ADR agreement. Consequently, our finding that these firms pay sizable and significantly lower dividends post-listing is inconsistent with any of the predictions of the legal bonding hypothesis. In the next section we attempt to shed more light on this finding.

\section{Firm level governance}

Our findings for Level 1 OTC firms may be consistent with the notion of reputational bonding: both King and Segal (2004) and Siegel (2004) document that even absent effec- 
tive legal bonding, a firm can still voluntarily bond themselves to fair treatment of their minority investors. In addition, the evidence from Section 3 suggests that Level 1 OTC firms from both strong and weak investor protection countries establish a strong reputation for the protection of investors by paying a greater proportion of their earnings as dividends, relative to both exchange-listed and Portal firms, and this relation holds in the pre and post-listing periods. Consequently, the ability of Level 1 OTC ADRs to pay lower dividends post-listing, may result from voluntary measures initiated by them post-listing, e.g. firm level governance improvements (e.g., Durnev \& Kim, 2005) and/or as a direct result of their reputation for fair treatment of minority shareholders. In fact Pinnegar and Ravichandran (2004, p. 8) in their study of Rule 144a/Reg S firms suggest as much when they conclude that "the reputation of the issuer may be as important as ownership concentration or the legal environment in protecting minority shareholders rights". The valuation premiums that Level 1 OTC firms generate post-listing are also consistent with the notion that these firms benefit from reputational bonding, post-listing (e.g., Durand, Tan, \& Tarca, 2005).

To examine whether non-exchange-listed firms (Level 1 OTC and SEC Rule 144a) voluntarily commit to bond themselves to fair treatment of their minority shareholders through improved firm-level governance, we proxy for firm-level governance using the number of closely held shares and examine its behaviour around a cross-listing. A fall in the number of closely held shares implies an improvement in firm-level governance. Numerous recent papers have employed closely held shares to proxy for firm-level governance (e.g., Holland $\&$ Warnock, 2003). From our original sample of 496 cross-listed firms, we are able to source from Worldscope data on Closely Held Shares for 214 Level 1 OTC firms, 137 Level 2/3 ADRs (including ordinary lists) and 49 SEC Rule 144a Portal firms. The results are outlined in Table 4.

In Table 4, we outline for each ADR level, the median value of closely held shares in the two years prior to listing, and on the list year. In the subsequent rows, we calculate the change in closely held shares between the five year post-listing $(1,2,3,4,5)$ period and the two years pre-listing $(-2,-1)$, i.e. $[\Delta(1,-2), \Delta(1,-1), \Delta(2,-2), \Delta(2,-1)$, $\Delta(3,-2), \Delta(3,-1), \Delta(4,-2), \Delta(4,-1), \Delta(5,-2), \Delta(5,-1)]$. For example, $\Delta(3,-1)$ refers to the change in closely held shares one year prior to listing to three years postlisting. In the case of OTC firms this change is negative, implying an improvement in firmlevel governance. In the remaining rows of Table 4, we outline the median value of closely held shares in the pre and post-listing period. The difference is outlined in the final row. We begin by discussing the results for Level 1 OTC firms. Our findings suggest that nonexchange-listed Level 1 firms improve their firm level governance in the post-listing period. For example, the number of shares closely held is lower in almost every period post-listing, relative to the two years pre-listing. The number of shares closely held by Level 1 OTC firms is almost $33 \%$ lower three years post-listing relative to the year prior to listing. We find the opposite for SEC Rule 144a firms; in every period post-listing, we find that the level of closely held shares is greater than in the pre-listing period (column 4). Interestingly, the results for both Level 1 OTC and SEC Rule 144a firms are consistent with our findings reported in Section 3: Level 1 OTC firms consistently pay higher dividends relative to both Level 2/3 exchange-listed firms, and SEC Rule 144a firms. As such these firms establish a reputation for fair treatment of their investors by paying out a sizable proportion of their earnings as dividends. Interestingly, the results for Level $2 / 3$ exchange-listed firms are mixed. 
Table 4

Before/after closely held shares for cross-listed firms

\begin{tabular}{llll}
\hline & $\begin{array}{l}\text { Level 1 OTC, } \\
\text { median CHS }\end{array}$ & $\begin{array}{l}\text { Level 2/3 exchange, } \\
\text { median CHS }\end{array}$ & $\begin{array}{l}\text { Rule 144a portal, } \\
\text { median CHS }\end{array}$ \\
\hline-2 & 85,116 & 37,604 & 15,476 \\
-1 & 101,690 & 40,830 & 15,113 \\
List year & 88,581 & 53,168 & 33,570 \\
$\Delta(1,-2)$ & 14,783 & 6,569 & 4,830 \\
$\Delta(1,-1)$ & $(1,791)$ & 3,343 & 5,193 \\
$\Delta(2,-2)$ & 871 & $(5,996)$ & 32,574 \\
$\Delta(2,-1)$ & $(15,703)$ & $(9,222)$ & 32,937 \\
$\Delta(3,-2)$ & $(16,346)$ & 8,278 & 45,331 \\
$\Delta(3,-1)$ & $(32,920)$ & 5,052 & 45,694 \\
$\Delta(4,-2)$ & $(15,499)$ & 11,410 & 11,295 \\
$\Delta(4,-1)$ & $(32,073)$ & 8,184 & 11,653 \\
$\Delta(5,-2)$ & 592 & $(12,670)$ & 11,295 \\
$\Delta(5,-1)$ & $(15,982)$ & $(15,896)$ & 11,658 \\
Before & 73,830 & 44,266 & 10,080 \\
After & 80,707 & 48,453 & 23,484 \\
Difference & 6,877 & 4,187 & 13,404 \\
\hline
\end{tabular}

In the preceding table we report before/after estimates of closely held shares (firm governance) for firms that cross-list in the United States. We report the median closely held share value for firms that list either as Level 1 OTC ADRs $(n=214)$, exchange-listed level 2/3 ADRs $(n=137)$ and ordinary lists, or that trade under SEC Rule 144a on Portal $(n=49)$. Closely held shares (CHS) are shares held by insiders and is provided by Worldscope. We calculate the change in CHS between the five year post-listing $(1,2,3,4,5)$ period and the two years pre-listing $(-2,-1)[\Delta(1,-2), \Delta(1,-1), \Delta(2,-2), \Delta(2$, $-1), \Delta(3,-2), \Delta(3,-1), \Delta(4,-2), \Delta(4,-1), \Delta(5,-2), \Delta(5,-1)]$.

\section{Concluding remarks}

The ability of firms to finance their investment opportunity set externally is largely contingent on the effectiveness of their domestic legal system to protect the interests of their minority shareholders. In a country characterised by poor legal protection of investors, firms are very often constrained in their attempts to fund their growth opportunities. To rectify this, a number of firms have, over the course of the last decade sought to substitute their home level governance for the superior governance of the U.S. by listing on an organised U.S. exchange. Reese and Weisbach (2002) document that, exchange-listed ADRs capitally constrained at home pre-listing, were no longer post-listing. This line of reasoning suggests that the domestic investors of these firms are better protected post-listing. We test this proposition.

In order to do so we employ the agency models of dividends introduced by LLSV (2000). We examine the ordinary dividend payout of cross-listed firms around a cross-listing in the U.S. Our choice of variable is motivated by the fact that (1) dividend payout is increasing in the level of investor protection (La Porta et al., 2000) and, consequently (2) changes in external investor protection are associated with changes in firm dividend payout (Liu, 2002), controlling for firm, industry and country level determinants of dividend payout. We hypothesise that if the investors of exchange-listed firms are better protected, firms are more likely to pay lower dividends. We argue that ordinary shareholders are compensated for this reduced dividend payment with enhanced protection. 
Using a sample of 496 cross-listed firms from forty countries, we show that exchange-listed firms pay significantly lower dividends post-listing, and this finding is robust to the inclusion of firm, industry and country controls. This result is consistent with the notion that these investors are better protected under the U.S. regime. In line with our expectations we find no evidence that the ordinary shareholders of Rule 144a firms benefit from incremental protection, post-listing. Interestingly, our results suggest that the minority investors of Level 1 OTC firms are better protected. Although inconsistent with the legal bonding hypothesis, we show that these firms consistently establish a reputation for better protection of their investors by paying out a greater proportion of their earnings as dividends. Consequently, their ability to pay lower dividends post-list may well result from a voluntary commitment on the part of these firm to protect their investors that is credible given their reputation for fair treatment. We show that there is evidence to suggest that these firms improve their firm level governance post-listing. The payment of substantially higher dividends by these firms suggests a commitment on their part to bond to fair treatment of their ordinary shareholders.

Finally, our findings outline the importance of testing the agency models of dividends both cross-sectionally, and across time. Like Liu (2002), we find empirical support in favour of both models; dividend payouts are larger in countries where investors are better protected. In addition we show that this relationship has persisted over time. Second, and consistent with the findings of Liu (2002), we show that governance reforms are associated with lower firm dividend payouts. Liu's (2002) findings suggest that country functional convergence reforms (as opposed to legal reforms) substitute for dividends in controlling the agency costs associated with free cash flow. Our findings suggest that governance reforms initiated at the level of the firm, and not the country, are effective reforms. This suggests that cross-listing in the U.S. does enhance the protection of the domestic investors of those firms that list.

\section{Acknowledgements}

The author is indebted to Thomas Flavin, Donal O'Neill, Denis Conniffe and Gerard Dwyer Jnr for comments on an earlier version of the paper. The paper has also benefited from comments from seminar participants at the Money Macro Finance (MMF) Annual Conference 2004 at the CASS Business School London, and the 3rd INFINITI Conference at Trinity College Dublin 2005, notably Aktar Siddique, Mahua Bararri (discussant) and the editors Brian Lucey and Svitlana Voronkova. The usual disclaimers apply. 
Appendix A. American depositary receipts (ADR) characteristics

\begin{tabular}{|c|c|c|c|c|}
\hline & Level I & Level II & Level III & $144 \mathrm{a}$ \\
\hline Primary exchange & OTC 'pink sheets' & $\begin{array}{l}\text { NYSE, AMEX, or } \\
\text { NASDAQ }\end{array}$ & $\begin{array}{l}\text { NYSE, AMEX, or } \\
\text { NASDAQ }\end{array}$ & PORTAL $^{1}$ \\
\hline Accounting standards & Home country & U.S. GAAP & U.S. GAAP & Home country \\
\hline U.S. reporting requirements & $\begin{array}{l}\text { Exempt Rule } \\
12 \mathrm{~g} 3-2(\mathrm{~b}), \\
\text { compliance }^{2} \text {, } \\
\text { securities act of } \\
1934\end{array}$ & $\begin{array}{l}\text { Form } 20-\mathrm{F}^{3} \text { and } \\
\text { Form } 6-\mathrm{K} \text {, } \\
\text { securities act of } \\
1934\end{array}$ & $\begin{array}{l}\text { Form 20-F } \\
\text { (annual) and Form } \\
\text { 6-K, securities act } \\
\text { of } 1934\end{array}$ & Exempt Rule $12 \mathrm{~g} 3-2$ (b), compliance or Rule $144 \mathrm{a}$ \\
\hline SEC registration & Exempt & Full registration & Full registration & Exempt \\
\hline Equity issuance & $\begin{array}{l}\text { Existing shares } \\
\text { only (public } \\
\text { offering) }\end{array}$ & $\begin{array}{l}\text { Existing shares } \\
\text { only (public } \\
\text { offering) }\end{array}$ & $\begin{array}{l}\text { New equity capital } \\
\left(\text { public offering }^{4}\right)\end{array}$ & New equity capital (private offering to QIBs ${ }^{5}$ ) \\
\hline Time to completion & 10 weeks & 10 weeks & 14 weeks & 16 days \\
\hline Costs & $<\$ 25,000$ & $\$ 200,000-700,000$ & $\$ 500,000-2,000,000$ & $\$ 250,000-500,000$ \\
\hline
\end{tabular}

Sources: Citibank, Deutsche Bank, Bank of New York.

${ }^{1}$ PORTAL is an acronym for private offerings, resales and trading through automated linkages.

${ }^{2}$ Under certain circumstances, the SEC exempts non-U.S. corporations wishing to trade their shares in the U.S. from the full reporting burden. The Information Supplying

Exemption, also known as Rule 12g 3-2(b), can be obtained by those non-U.S. corporations that are not seeking a listing on a national exchange and are not intending to launch a public offering of their securities.

3 A Form 20-F is filed as a registration statement/annual report by issuers of Level II or III sponsored ADR/GDR. It is a comprehensive report of all material business activities and financial results and must comply with U.S. GAAP. The Form 20-F consists of four parts. Part I requires a full description of the issuers business, details of its property, any outstanding legal proceedings, taxation and any exchange controls that might effect security holders. Part II requires a description of any securities to be registered, the name of the depositary bank for the DRs and all fees to be charged to the holders of DRs. Part III contains information on any defaults upon senior securities. Part IV requires various financial statements to be submitted.

${ }^{4}$ Foreign Issuers planning a public offering in the U.S. via a Level III ADR must register the proposed new securities by filing Form F-1.

5 Qualified institutional buyers (QIBs) are investors eligible to participate in the Rule 144a Market. The SEC defines these primarily as institutions that manage at least $\$ 100$ million in securities including banks, savings and loans, insurance companies, investment companies, public employee benefit plans, employee benefit plans under ERISA, or an entity owned entirely by qualified investors. Also included are registered broker-dealers owning and investing, on a discretionary basis, $\$ 10$ million in securities of non affiliates. 


\section{Appendix B. Variable descriptions}

\begin{tabular}{|c|c|c|c|c|}
\hline Variable & Sign & Abbreviation & Source & Description \\
\hline Dividends-to-earnings & N/A & Div/Earn & Worldscope & $\begin{array}{l}\text { Dividends per share represent the } \\
\text { total amount of dividends declared } \\
\text { during the year, earnings per share } \\
\text { represent the earnings for the year }\end{array}$ \\
\hline Dividends-to-cashflow & N/A & Div/CF & Worldscope & $\begin{array}{l}\text { Dividends per share represent the } \\
\text { total amount of dividends declared } \\
\text { during the year, cash flow per share } \\
\text { represents the cash earnings per share } \\
\text { of the company }\end{array}$ \\
\hline Market-to-book assets & - & MBA & Datastream & $\begin{array}{l}\text { Also called discount to net asset } \\
\text { value, divides the market value by the } \\
\text { net book value }\end{array}$ \\
\hline Free-cash-flow & + & FCF/net sales & Worldscope & $\begin{array}{l}\text { Earnings before interest and taxation } \\
(\text { EBIT) + depreciation depletion and } \\
\text { amortization (DDA) - capital } \\
\text { expenditures }\end{array}$ \\
\hline Debt & - & Debt/net sales & Worldscope & $\begin{array}{l}\text { Total debt represents all interest } \\
\text { bearing and capitalized lease } \\
\text { obligations. It is the sum of long and } \\
\text { short term debt }\end{array}$ \\
\hline Cost of goods sold & - & COGS/net sales & Worldscope & $\begin{array}{l}\text { COGS represents specific or direct } \\
\text { manufacturing cost of labour and } \\
\text { material in the production of finished } \\
\text { goods }\end{array}$ \\
\hline Return on equity & + & ROE & Worldscope & $\begin{array}{l}\text { EPS divided by the book growth per } \\
\text { share (expressed as a \%) }\end{array}$ \\
\hline EPS volatility & - & EPS & Worldscope & $\begin{array}{l}\text { The variance of the previous three } \\
\text { years EPS }\end{array}$ \\
\hline Net sales & N/A & - & Worldscope & $\begin{array}{l}\text { Represents gross sales and other } \\
\text { operating revenue less discounts, } \\
\text { returns and allowances }\end{array}$ \\
\hline Log (total assets) & + & Log (total assets) & Worldscope & $\begin{array}{l}\text { Total assets represents the sum of } \\
\text { total current assets, long term } \\
\text { receivables, investment in } \\
\text { unconsolidated subsidiaries, other } \\
\text { investments, net property plant and } \\
\text { equipment and other assets }\end{array}$ \\
\hline D (law) & + & Common law & LLSV (2000) & $\begin{array}{l}\mathrm{D}=1 \text { the firm originates from a } \\
\text { common law country }\end{array}$ \\
\hline D (investor protection) & + & Anti-director & LLSV (1998) & $\begin{array}{l}\mathrm{D}=1 \text { if a firm originates in a country } \\
\text { where investors are highly protected } \\
\text { (anti-director rights } \geq \text { median of } 3 \text { ) }\end{array}$ \\
\hline Industry dummies & N/A & & Worldscope & $\begin{array}{l}\text { Primary standard classification codes } \\
\text { (SIC). }\end{array}$ \\
\hline ADR dividend & \pm & ADR dividend & Bank of New York & $\mathrm{D}=1$ if a firm pays an ADR Dividend \\
\hline
\end{tabular}


Appendix C. Correlation coefficient matrix and variance-inflation factors

\begin{tabular}{|c|c|c|c|c|c|c|c|c|c|c|}
\hline & Div/Earn & Div/CF & COGS & ROE & Earn Vol & FCF & Debt & MBA & $\log (\mathrm{TA})$ & VIF (DE) \\
\hline Div/Earn & 1 & & & & & & & & & - \\
\hline Div/CF & $0.5937^{* * *}$ & 1 & & & & & & & & - \\
\hline COGS & $-0.0116^{* *}$ & $-0.0315^{* * *}$ & 1 & & & & & & & 1.01 \\
\hline ROE & $0.0206^{* * *}$ & $0.1442^{* * * *}$ & $-0.0446^{* * *}$ & 1 & & & & & & 1.08 \\
\hline Earnings volatility & $-0.0310^{* * * *}$ & $-0.0443^{* * *}$ & $0.0202^{* * *}$ & $-0.0233^{* * *}$ & 1 & & & & & 1.00 \\
\hline Free cash flow & -0.0029 & -0.0050 & -0.0008 & -0.0084 & 0.0006 & 1 & & & & 1.00 \\
\hline Debt & -0.0070 & -0.0060 & -0.0005 & $-0.0116^{* * *}$ & 0.0012 & $0.5411^{* * *}$ & 1 & & & 1.01 \\
\hline Market book assets & $-0.0303^{* * *}$ & $0.0159^{* * *}$ & $-0.0647^{* * *}$ & $0.1730^{* * *}$ & $-0.0206^{* * *}$ & -0.0065 & -0.0028 & 1 & & 1.06 \\
\hline Log (total assets) & $0.0984^{* * *}$ & $-0.0153^{* * *}$ & $-0.0288^{* * *}$ & $-0.1240^{* * *}$ & $0.0206^{* * * *}$ & $-0.0361^{* * *}$ & $-0.0598^{* * *}$ & $-0.0540^{* * *}$ & 1 & 1.03 \\
\hline
\end{tabular}

In this table we outline Pearson correlation coefficients for our dependent variables and all our independent variables. In addition, we outline employing both variants of our dependent variable, variance-inflation factors (VIFs). The variance-inflation factors are defined as $(1 /(1-R))$, where $R^{2}$ is from a regression (pooled) of an explanatory variable on a constant and the remainder of the explanatory variables. All of the variables are defined in appendix.

** Significance at the $5 \%$ level of significance.

*** Significance at the $1 \%$ level of significance. 


\section{References}

Aggarwal, R., Dahiya, S., \& Klapper, L. (2005). American Depositary Receipts (ADR) holdings of U.S. based emerging market funds (Georgetown University Working Paper).

Barzuza, M. (2005). Cross-listing, asymmetric information and private benefits of control (Harvard Law School Working Paper).

Baum, C. F. (2001). Residual diagnostics for cross-section time series regression models. Stata Journal, 1, $101-104$.

Benos, E., \& Weisbach, M. (2004). Private benefits and cross listing in the United States. Emerging Markets Review, 5 , 217-240.

Carvalho, A., \& Pennacchi, G. (2005). Can voluntary market reforms promote efficient corporate governance? Evidence from firms' migration to premium markets in Brazil (University of Illinois Discussion Paper).

Chamberlain, G. (1984). Panel data. In Z. Griliches, M. D. Intriligator (Eds.), Handbook of econometrics (Vol. II, pp. 1247-1318), North Holland.

Coffee, J. (1999). The future as history: The prospects for global convergence in corporate governance and its implications. Northwestern University Law Review, 93, pp. 641-708.

Coffee, J. (2002). Racing towards the top: The impact of cross-listings and stock market competition on international corporate governance. Columbia Law Review, 102, 1757-1831.

DeAngelo, H., DeAngelo, L., \& Skinner, D. (2003). Are dividends disappearing? Dividend concentration and the consolidation of earnings. Journal of Financial Economics.

Demerguc-Kunt, A., \& Maksimovic, V. (1998). Law, finance and firm growth. Journal of Finance, 53, 21072137.

Dewenter, K. L., Kim, C. -S., Lim, U., \& Novaes, W. (2005). Committing to protect investors in emerging markets: Can local exchanges provide value-relevant bonding mechanisms? (University of Washington Working Paper).

Doidge, C. (2004). U.S. cross-listings and the private benefits of control: Evidence from dual class firms. Journal of Financial Economics, 72, 519-533.

Doidge, C., Karolyi, G. A., \& Stulz, R. M. (2004). Why are foreign firms listed in the U.S. worth more? Journal of Financial Economics, 71, 205-238.

Doidge, C., Karolyi, G. A., \& Stulz, R. M. (2004b). Why do country characteristics matter so much for corporate governance? (European Corporate Governance Institute Discussion Paper).

Doidge, C., Karolyi, G. A., Lins, K. V., Miller, D., \& Stulz, R. M. (2005). Private benefits of control, ownership, and the cross-listing decision (European Corporate Governance Institute (ECGI) Working Paper no. 77).

Drukker, D. M. (2003). Testing for serial correlation in linear panel-data models. Stata Journal, 3(2), $168-177$.

Durand, R. B., Tan, J., \& Tarca, A. (2005). Foreign firms in the less-regulated U.S. market (University of Western Australia Working Paper).

Durnev, A., \& Kim, E. H. (2005). To steal or not to steal: Firm attributes, legal environment, and valuation. Journal of Finance, 60, 1461-1493.

Easterbrook, F. H. (1984). Two agency-cost explanations of dividends. American Economic Review, 74, 650-659.

Fama, E. F., \& French, K. R. (2002a). Disappearing dividends: Changing firm characteristics or lower propensity to pay? Journal of Financial Economics.

Fama, E. F., \& French, K. R. (2002b). Testing tradeoff and pecking order predictions about dividends and debt. Review of Financial Studies, 15, 1-33.

Fazzari, S. M., Hubbard, R. G., \& Petersen, B. C. (1988). Financing constraints and corporate investment (Brookings Papers on Economic Activities).

Hail, L., \& Leuz, C. (2003). International differences in cost of capital: Do legal institutions and securities regulation matter? (University of Pennsylvania Working Paper).

Hardin, J. (2005). How can I get robust standard errors for Tobit? STATA Frequency Asked Questions.

Holland, S. B., \& Warnock, F. E. (2003). Firm-level access to international capital markets: Evidence from Chilean equities. Emerging Markets Review, 4, 39-51.

Hwang, L. S., Park, K., \& Park, R. (2004). Do firms with good corporate governance practices pay more dividends? Evidence from Korean business groups (Chung-Ang University Seoul Working Paper).

Ikenberry, D., \& Julio, L. D. (2004). Reappearing dividends. Journal of Applied Corporate Finance.

Jensen, M. C. (1986). Agency costs of free cash flow, corporate finance, and takeovers. American Economic Review, 76, 323-339.

Joos, P. (2003). Discussion of how representative are firms that are cross-listed in the United States? An analysis of accounting quality. Journal of Accounting Research, 41, 387-396.

King, M., \& Segal, D. (2004). International cross-listing and the bonding hypothesis (Bank of Canada Working Paper). 
Klapper, L. F., \& Love, I. (2004). Corporate governance, investor protection, and performance in emerging markets. Journal of Corporate Finance, 10, 723-728.

Krishnamurti, C., Sequeira, \& Fangjian, F. (2003). Stock exchange governance and market quality. Journal of Banking and Finance, 27, 1859-1878.

Lang, M. H., Lins, K. V., \& Miller, D. (2002). ADR's, analysts, and accuracy: Does cross-listing in the U.S. improve a firm's information environment and increase market value? Journal of Accounting Research, 41, 317-345.

La Porta, R., Lopez-de-Silanes, F., Shleifer, A., \& Vishny, R. (1998). Law and finance. Journal of Political Economy, 106, 1113-1155.

La Porta, R., Lopez-de-Silanes, F., Shleifer, A., \& Vishny, R. (2000). Agency problems and dividend policies around the world. Journal of Finance, LV(1), 1-33.

Leuz, C., \& Obelholzer-Gee, F. (2006). Political relationships, global financing, and corporate transparency: Evidence from Indonesia. Journal of Financial Economics, forthcoming.

Licht, A. N. (2003). Cross-listing and corporate governance: Bonding or avoiding? Chicago Journal of International Law, $4,141-163$.

Licht, A. N. (2004). Legal plug-ins: Cultural distance, cross-listing, and corporate governance reform. Berkeley Journal of International Law, 4, 141-163.

Lins, K., Strickland, D., \& Zenner, M. (2005). Do non-U.S. firms issue equity on U.S. stock exchanges to relax capital constraints? Journal of Financial and Quantitative Analysis, 40, 109-133.

Liu, W. (2002). Do dividends substitute for the external corporate governance? A cross-country dynamic view (Indiana State University Working Paper).

Mitton, T. (2004). Corporate governance and dividend policy in emerging markets. Emerging Markets Review, 5, 409-426.

Mundlak, Y. (1978). On the pooling of time series and cross section data. Econometrica, 1, 69-85.

Petersen, M. A. (2005). Estimating standard errors in finance panel data sets: comparing approaches (NBER Working Paper No. W11280).

Pinegar, J. M., \& Ravichandran, R. (2004). When does bonding bond? The case of ADRs and GDRs (Working Paper).

Reese, W., \& Weisbach, M. (2002). Protection of minority shareholder interests, cross-listings in the United States, and subsequent equity offerings. Journal of Financial Economics, 66, 65-104.

Ribstein, L. E. (2005). Cross-listing and regulatory competition. Review of Law and Economics, 1, 97-148.

Rogers, W. (1993). Regression standard errors in clustered samples. Stata Technical Bulletin, 13, 19-23.

Rozeff, M. S. (1982). Growth, beta, and agency costs as determinants of dividend payout ratios. Journal of Financial Research, 5, 249-259.

Siegel, J. (2003). Do foreign firms choose not to cross-list because they have secured better alternatives? Evidence from Mexico (Harvard Business School Working Paper).

Siegel, J. (2005). Can foreign firms bond themselves effectively by renting U.S. securities laws? Journal of Financial Economics, 75(2), 319-359.

Stulz, R. (1999). Globalisation, corporate finance, and the cost of capital. Journal of Applied Corporate Finance, 12, $8-25$.

Stulz, R. (2005). The limits of financial globalisation. Journal of Finance, 60, 1595-1638.

Wiggins, V. (2003). How do I test for panel-level heteroscedasticity and autocorrelation? STATA Frequently Asked Questions.

Wooldridge, J. M. (2002). Econometric analysis of cross-section and panel data. Cambridge, MA: MIT Press.

Zhang, R. (2005). The effects of firm and country-level governance mechanisms on dividend policy, cash holdings, and firm value: A cross-country study (University of Tennessee Working Paper). 